\title{
Geophysical investigations in the Radovna River Spring area (Julian Alps, NW Slovenia)
}

\section{Geofizikalne raziskave na območju izvira reke Radovne (Julijske Alpe, SV Slovenija)}

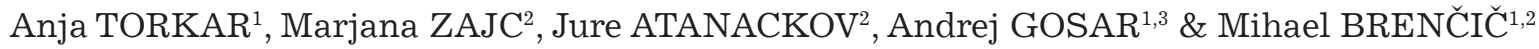 \\ ${ }^{1}$ Faculty of Natural Sciences and Engineering, University of Ljubljana, Aškerčeva c. 12, SI-1000 Ljubljana, \\ Slovenia; e-mail: anja.torkar@ntf.uni-lj.si, mihael.brencic@ntf.uni-lj.si \\ ${ }^{2}$ Geological Survey of Slovenia, Dimičeva ulica14, SI-1000 Ljubljana, Slovenia; \\ e-mail: marjana.zajc@geo-zs.si,jure.atanackov@geo-zs.si
}

${ }^{3}$ Slovenian Environment Agency, Seismology and Geology Office, Vojkova 1b, SI-1000 Ljubljana, Slovenia; e-mail: andrej.gosar@gov.si

Prejeto / Received 3. 11. 2021; Sprejeto / Accepted 7. 12. 2021; Objavljeno na spletu / Published online 28. 12.2021

Key words: Ground penetrating radar, Seismic reflection method, Radovna spring, hydrogeology, aquifer geometry, glacial valley, groundwater table

Ključne besede: Georadar, refleksijska seizmika, izvir Radovne, hidrogeologija, geometrija vodonosnika, ledeniška dolina, gladina podzemne vode

\begin{abstract}
The Radovna River Valley is located in the north-western part of Slovenia in the Julian Alps, where there is an extensive intergranular aquifer whose depth to pre-Quaternary bedrock is unknown. Therefore, to obtain information about the depth of the valley and the geometry of the aquifer two geophysical methods were used in our study; ground penetrating radar (GPR) and seismic reflection method. The low-frequency GPR method has shown to be useful for determining the depth of the groundwater and the predominant groundwater recharge. Also, the high-resolution seismic method provided an insight about the morphology of the pre-Quaternary basement with the deepest point at 141 meters below surface. Measurements of hydrogeological parameters such as groundwater level and river discharge measurements were carried out in the study area. Both data analyses showed that groundwater level and river discharge are highly fluctuating and rapidly changing, indicating a well-permeable aquifer, implying that such an aquifer is extremely sensitive and vulnerable to extreme climate events. Both the geophysical methods and the hydrogeological information have provided important information about the morphology of the valley and the alluvial aquifer, as well as increasing the knowledge about the Radovna springs system, which will contribute very important information for future hydrogeological studies.
\end{abstract}

\section{Izvleček}

Dolina reke Radovne leži v severozahodnem delu Slovenije na območju Julijskih Alp, kjer se nahaja obsežen medzrnski vodonosnik, katerega globina do predkvartarne podlage ni znana. Zato smo v naši raziskavi za pridobitev podatkov o globini doline in geometriji vodonosnika uporabili dve geofizikalni metodi; georadar in metodo seizmične refleksije. Metoda nizkofrekvenčnega georadarja se je izkazala za uporabno pri določanju globine podzemne vode in smeri prevladujočega napajanja podzemne vode. Tudi seizmična metoda visoke ločljivosti je omogočila vpogled v morfologijo predkvartarne podlage z najglobljo točko 141 metrov pod površjem. Na območju raziskav so bile opravljene tudi meritve hidrogeoloških parametrov, kot so gladina podzemne vode in pretok v reki. Analiza obeh parametrov je pokazala, da nivo podzemne vode in rečni pretok močno nihata in se hitro spreminjata, kar pomeni, da je tak vodonosnik izjemno občutljiv in ranljiv za ekstremne podnebne dogodke. Tako geofizikalne metode kot hidrogeološki podatki predstavljajo pomembne informacije o morfologiji doline in aluvialnega vodonosnika, prav tako je znanje o sistemu izvirov Radovne večje, kar bo predstavljalo pomemben doprinos pri hidrogeoloških raziskavah v prihodnje. 


\section{Introduction}

Characterization of the lithology, stratigraphic features and geometry of the aquifer is essential component of modern hydrogeological studies. Quantification of these attributes is difficult in many aquifers, especially where the aquifers consist of alluvial and glacial deposits (Bowling et al., 2007). The sediments in such aquifers consist of different grain sizes and sorting, making it difficult to adequately characterize the hydraulic properties of the aquifer through direct observations. Knowledge of the geometry of the aquifer and definition of the key geometric elements are of great importance for studying hydrogeology and water balance in particular area. The most accurate way to define the depth of the aquifer is with existing or new boreholes. The cost of several boreholes can be a limitation, as was also in our case, in addition to other characteristics of the location. The investigated area, the Radovna spring, is located in the Julian Alps (Fig. 1), inside the Triglav National Park, where traditional hydrogeological methods of investigations are difficult to apply and are restricted. In the Radovna Valley interaction between karstic and intergranular aquifers is present and this is reflected in the water dynamics and also in chemical and isotopic characteristics of the water. The fluvioglacial sediments are composed of a heterogeneous mix of fine-grained and coarse-grained materials and it is difficult to drill enough boreholes for sufficient characterization of the aquifer (McClymont et al., 2012). For these reasons, the definition of the aquifer geometry in this study has been achieved through application of non-invasive geophysical methods.

In the past several independent geological and hydrogeological studies were carried out in the Radovna Valley, but their results are not published and are mainly available in the archive of the Geological Survey of Slovenia and are in details described elsewhere (Torkar \& Brenčič, 2015). The investigated area of the Radovna River system is a unique study case for its interaction between karstic and intergranular aquifers and therefore of great interest for hydrogeological studies. The area of the Radovna River is also the most important drinking water source in NW Slovenia supplying 29,700 inhabitants and studies in this area are important for future water management. Between 1960 and 1980 geological mapping was carried out with several shallow boreholes as a part of chalk exploitation in Sr. Radovna. In 1965 in the Krma Valley three boreholes were drilled for planned construction of a tourist cen- tre with the deepest borehole at $60 \mathrm{~m}$ still in the alluvial sediments. Hydrogeological and geomechanical investigations were done in 1977 in the middle part of the valley for a planned but never accomplished high dam water-storage reservoir. Three boreholes were drilled, on both sides of the valley and in the central part with the maximum depth at $103 \mathrm{~m}$. The borehole did not reach the pre-Quaternary basement. Recent studies are directed towards hydrogeological (Torkar \& Brenčič, 2015) and hydrogeochemical investigations of water (Kanduč et al., 2012; Torkar et al., 2016) and soil (Ferjan Stanič et al., 2013).

Despite all drilled boreholes, none of the boreholes did reached the pre-Quaternary bedrock. Therefore, there is a lack of information about the depth of the valley and the geometry of the aquifer for future hydrogeological investigations. The aims of this study were to determine the position of the groundwater table and the preferred direction of water recharge using ground penetrating radar (GPR) and to determine the depth of the intergranular aquifer and to reveal the pre-Quaternary bedrock topography with seismic reflection method.

\section{General Settings}

The Radovna spring is located in the north-western part of Slovenia in the Julian Alps in a typically U-shaped narrow glacial valley with very steep slopes. West from the Radovna Valley are glacial valleys Kot and Krma which together with considerable part of eastern Julian Alps represent the recharge area of the Radovna spring (Fig. 1). Both valleys are filled with highly permeable gravel. The altitude of the spring area is around $750 \mathrm{~m}$ a.s.l. and the average altitude of surrounding plateaus of Pokljuka and Mežakla are 1228 and $1106 \mathrm{~m}$ a.s.l. respectively. The slope of the Pokljuka plateau in the south is steeper than the slope of the Mežakla plateau in the north. The width of the Radovna River Valley varies in the upper part between 300 and 350 meters in the middle part it is around 250 meters and in the lower part it is the narrowest in the Vintgar gorge with only a few meters. The Radovna River flows almost entirely in the Triglav National Park and after its $19.4 \mathrm{~km}$ long course discharges into the Sava Dolinka River.

The Radovna spring is positioned in an Alpine region with an average air temperature between $-8{ }^{\circ} \mathrm{C}$ in January and $23.8{ }^{\circ} \mathrm{C}$ in July taken from the meteorological station Rateče (Lat. 46.50, Lon. 13.71, altitude $864 \mathrm{~m}, 20.7 \mathrm{~km}$ distance from the Radovna spring). The standard 30 -year 


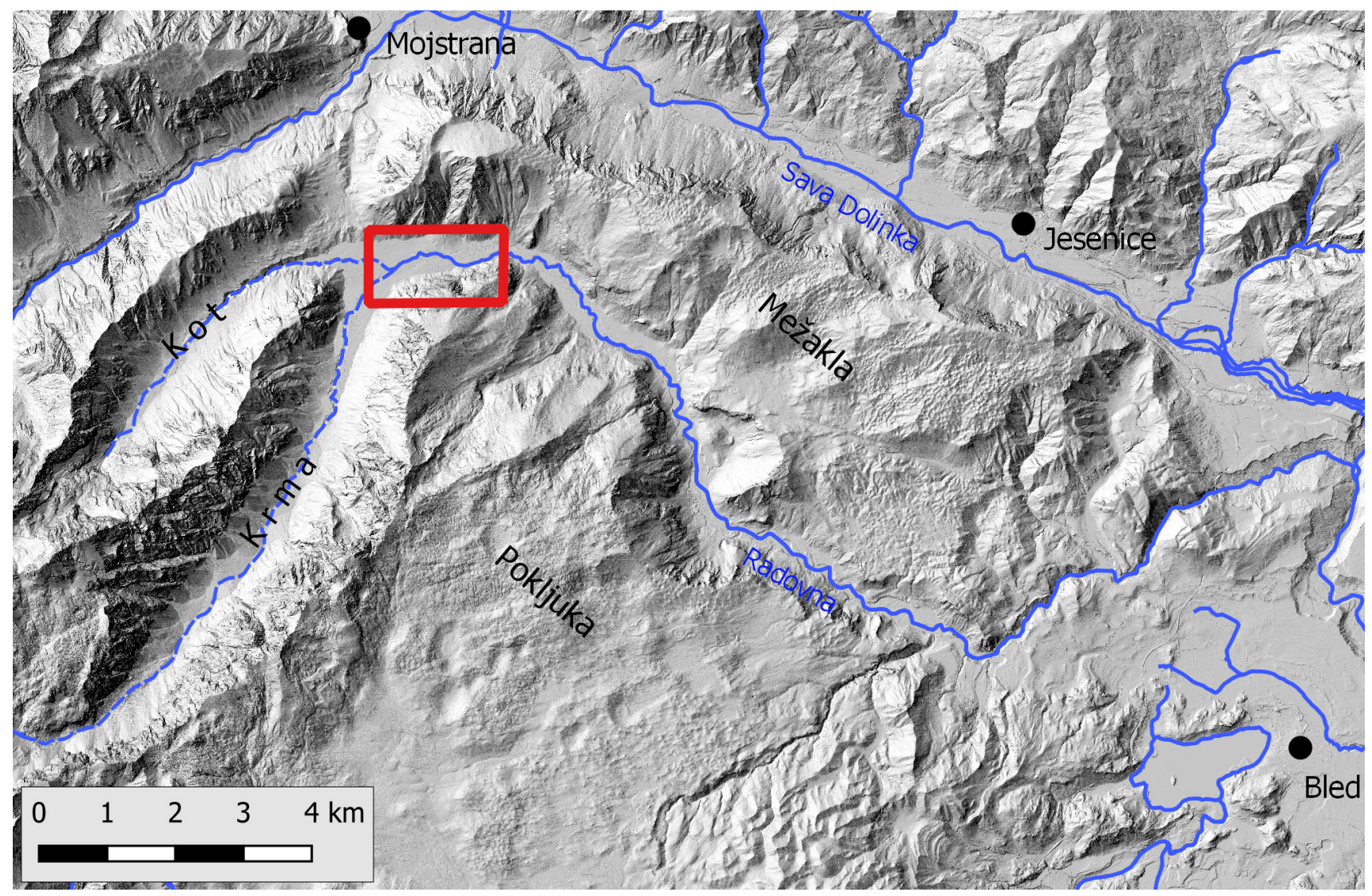

Fig. 1. Position map of the investigated area (red rectangle).

(1981-2010) average annual precipitation from the precipitation station Zg. Radovna is $1701 \mathrm{~mm}$. Highest amount of precipitation falls in the autumn with an average of $584 \mathrm{~mm}$ and the lowest in the winter with $346 \mathrm{~mm}$ (Nadbath, 2012).

\section{Geological and hydrogeological settings}

The broader study area, which includes the western part of the Mežakla and Pokljuka plateaus, the Kot and Krma Valleys and the eastern part of the Julian Alps, consists of Triassic limestone, dolomite and dolomitized limestone. In the Radovna Valley Quaternary fluvio-glacial sediments are present and are represented by gravel, sand and partly conglomerate with interbedded lenses of clay (Buser, 1980; Jurkovšek, 1987). In the central part of the valley, chalk deposits were exploited in the past (Iskra, 1982). Chalk mixed with sand occurs also in the north-western part of the valley, where geophysical investigations were conducted. Previous borehole data indicates that the local thickness of the Quaternary sediments in the valley is more than 100 meters (Torkar \& Brenčič, 2015).

The recharge area of the Radovna spring is karstified, where nearly all precipitation infiltrates into carbonate rocks and then drains into the alluvial intergranular aquifer and partly some in to the slope deposits. Groundwater in the karst-fractured aquifer and intergranular aquifer occurs in unconfined conditions. Groundwater recharge in the investigated area is very uneven, because snow is predominant form of precipitation in the winter and groundwater has limited recharge during this period. The groundwater table in the study area fluctuates for approximately 20 meters; consequently the Radovna spring changes its locations up and down the valley (up to $2 \mathrm{~km}$ ) due to different water conditions. The estimated average hydraulic conductivity of limestone and dolomite ranges from $10^{-5}$ to $10^{-7} \mathrm{~m} / \mathrm{s}$ and fluvio-glacial sediments with a wide range of average estimated permeability from $10^{-3}$ to $10^{-7} \mathrm{~m} / \mathrm{s}$.

\section{Methodology}

The geophysical methods used in our investigation were ground penetrating radar (GPR) and seismic reflection method. Both methods were used once on different profiles and time periods due to different purpose of research. For the additional information about the aquifer, instruments for measurements of groundwater level and river discharge were installed in the field. 


\section{Ground penetrating radar}

GPR is a non-invasive geophysical method used to investigate the shallow subsurface. Its application and operating principles have been described in various publications (e.g. Annan, 2002; Milsom, 2003; Neal, 2004; Blindow et al., 2007; Jol, 2009).High-frequency electromagnetic signals are emitted into the subsurface where they reflect from different discontinuities or structures back to the surface. The time it takes the signals to propagate from the transmitting antenna to the discontinuity and back to the receiving antenna (the so-called two-way travel time or TWT) is recorded and later converted to depth (Blindow et al., 2007; Jol, 2009). The depth range is mostly determined by the antenna frequency used, although it is also affected by other factors, such as the presence of water and clay (Jol; 2009). For the purpose of defining the depth to the water table, the GPR method has been proven useful in several studies to date (e.g. Doolittle et al., 2006; Mahmoudzadeh et al., 2012; Rejiba et al., 2012; Afshar et al., 2015; Paz et al., 2017).

For the purpose of this study, three GPR profiles were recorded (Figs. 2, 3) in October 2012 using the Malå ProEx GPR recording unit with an unshielded $50 \mathrm{MHz}$ Rough Terrain Antenna (RTA). The flexible tube-like shape of this antenna allows carrying out GPR research even in the most rugged terrain (e.g. Zajc et al., 2014, 2015). It is $9.25 \mathrm{~m}$ long, with the distance of $4 \mathrm{~m}$ between the transmitter and the receiver (Malå, 2009). The design of the antenna allowed us to manoeuver through very rough terrain in an overgrown forest, over roots and branches as well as under wires and electric fences.

The longitudinal profile $\mathrm{R} 1$ was recorded from the water well at the western end of the profile, which served as a control point due to the known depth of the water table, and along the slope to the location of the Radovna River springs themselves in the east. The purpose of this profile was to determine the position of groundwater table. In addition to the longitudinal profile, two transverse profiles $\mathrm{R} 2$ and $\mathrm{R} 3$ were recorded to determine whether or not there is a difference in recharge of groundwater from both surrounding plateaus, which could be seen as a slight inclination of the water table to the north or to the south. The transverse profiles also represented additional ways of checking the depth to groundwater levels at the intersections with the profile R1. Table 1 shows the basic data of the recorded GPR profiles.
In order to assure steady signal triggering with the measuring step of $0.2 \mathrm{~m}$, a device containing a measuring thread was used.

In order to apply topographic corrections to GPR profiles, GNSS coordinates were recorded every $50 \mathrm{~m}$ along the profile lines, as well as in areas with sudden topographic changes, such as dirt roads and dry riverbeds. The $\mathrm{x}$ and $\mathrm{y}$ coordinates were used to calibrate the length of the profiles, while the $z$ coordinate was used to determine the elevation of the terrain. During the recording of GPR profiles the locations of these control points were indicated on radargrams using markers.

Table 1. Basic data on recorded GPR profiles.

\begin{tabular}{|l|l|l|l|}
\hline Profile & $\mathrm{R} 1$ & $\mathrm{R} 2$ & $\mathrm{R} 3$ \\
\hline Type & longitudinal & transverse & transverse \\
\hline General direction & $\mathrm{W} \rightarrow \mathrm{E}$ & $\mathrm{S} \rightarrow \mathrm{N}$ & $\mathrm{S} \rightarrow \mathrm{N}$ \\
\hline Profile length $[\mathrm{m}]$ & 1070 & 217 & 354.5 \\
\hline
\end{tabular}

\section{Seismic reflection profiling}

High-resolution seismic reflection (HRS) method is a shallow, near-surface application of a well-established method regularly used in petroleum industry. It is based on the reflection of artificially generated seismic waves from subsurface structures. Seismic waves reflect on interfaces where the seismic impedance of the sediment or rock changes. Seismic impedance depends on density and seismic wave velocity, so rapid changes in grain size, compaction, lithification and fluid saturation cause reflection of seismic waves (Yilmaz \& Doherty, 2001; Yilmaz et al., 2008). The depth range and resolution of the HRS method is not strictly defined, rather the term encompasses seismic reflection surveys down to a depth of several hundred meters. HRS is regularly used in surveys of shallow aquifers and in neotectonic research, targeting recent deformations of young sediments (e.g. Kaiser et al., 2009).

The high-resolution seismic reflection profile HRS Radovna was acquired along a gravel road crossing the Radovna valley in July 2013 (Figs. $2,4)$. The active spread used $40 \mathrm{~Hz}$ geophones at $2 \mathrm{~m}$ spacing and 48 active channels, with the active spread in ,on end' geometry (Tab. 2). A 6-kg sledgehammer was used as a seismic source, stacking 4 to 10 strikes per shot point. Other seismic sources were also considered. The GISCO ESS100 accelerated weight drop, which produces 
significantly higher source energy (Atanackov \& Gosar, 2013) was not used due to support vehicle mechanical problems. A 12-gauge seismic shotgun was also considered, but was not used due unfavourable dry soil conditions which produces poor signal-to-noise ratio (Atanackov \& Gosar, 2013).

Two linked ABEM Terraloc VI 24-channel field seismographs were used for data recording. The full length of the HRS Radovna profile is $416 \mathrm{~m}$ with 185 shot gathers recorded in total (Tab. 2). Recording conditions were variable and data acquisition was stopped during periods of increased noise due to traffic. Since wind was almost constantly present, data acquisition could not be limited to intervals with low tor wind.
Table 2. HRS profile Radovna data acquisition parameters.

\begin{tabular}{|l|l|}
\hline \multicolumn{2}{|l|}{ HRS profile Radovna data acquisition parameters } \\
\hline Length & $416 \mathrm{~m}$ \\
\hline Shot gathers & 185 \\
\hline Active channels & 48 \\
\hline Geophones & $40 \mathrm{~Hz}$ \\
\hline Geophone interval & $2 \mathrm{~m}$ \\
\hline Active spread length & $94 \mathrm{~m}$ \\
\hline Active spread geometry &, on end \\
\hline Offset (shot point - 1st geophone) & $2 \mathrm{~m}$ \\
\hline Seismic source & 6 -kg sledgehammer \\
\hline Records length & $812 \mathrm{~ms}$ \\
\hline Sampling frequency & $1000 \mathrm{~Hz}$ \\
\hline
\end{tabular}

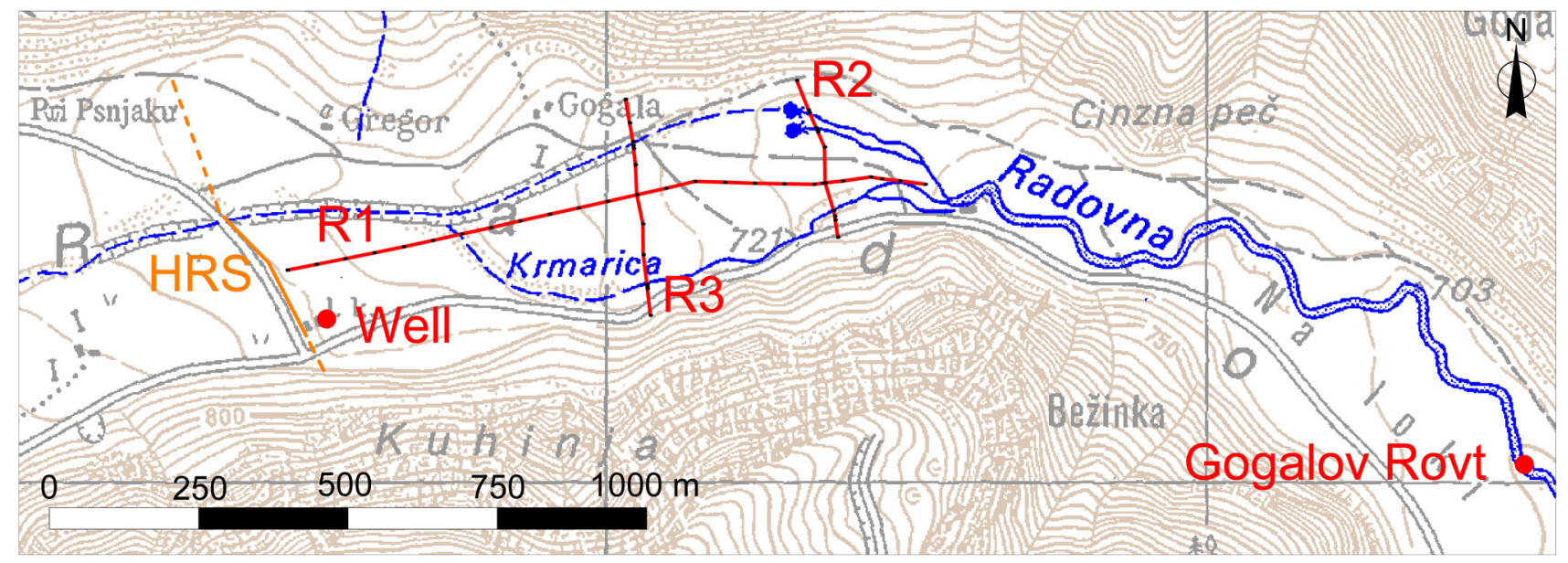

Fig. 2. Position map of seismic reflection profile HRS Radovna, GPR profiles R1, R2 and R3 and location of a well and Gogalov Rovt water level measurement station. Dashed orange line is extrapolation of the HRS profile shown in Fig. 8.

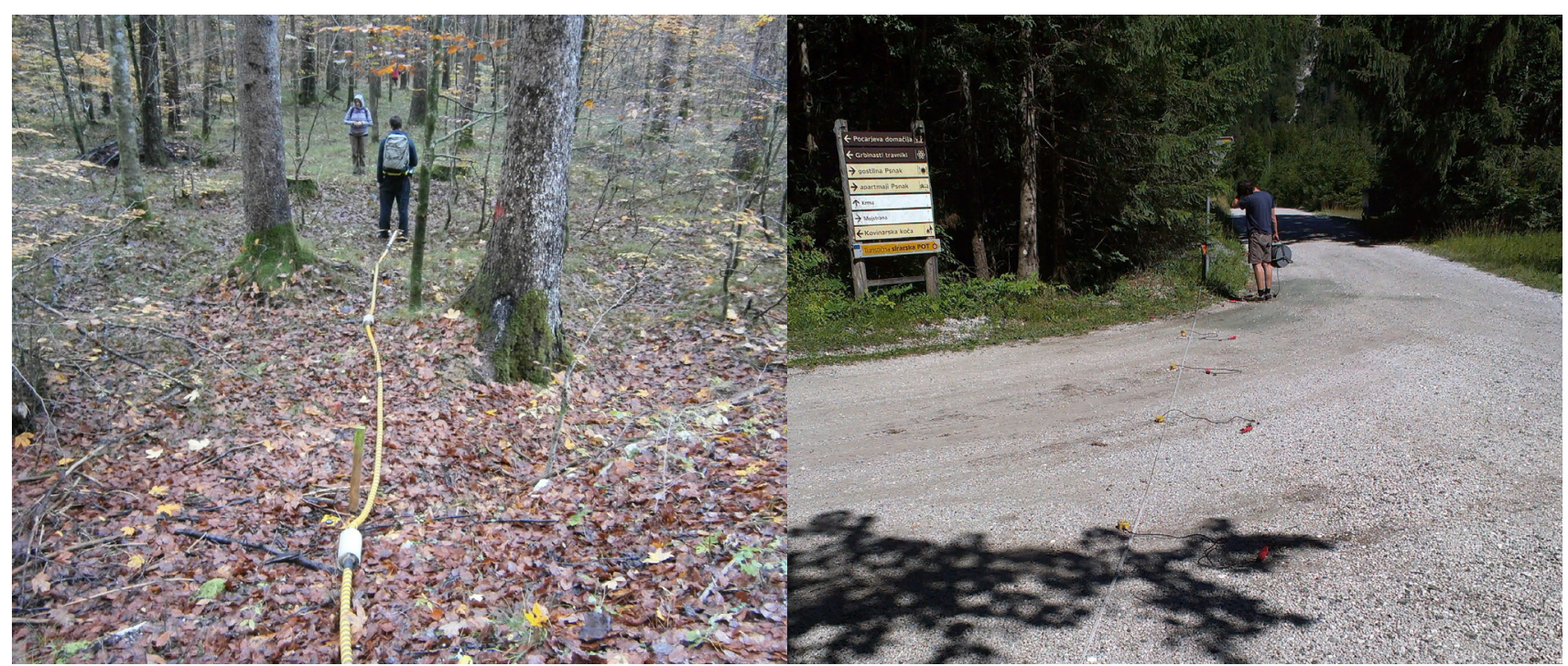

Fig. 3. Part of R1 profile in the field.
Fig. 4. Part of HRS profile in the field. 


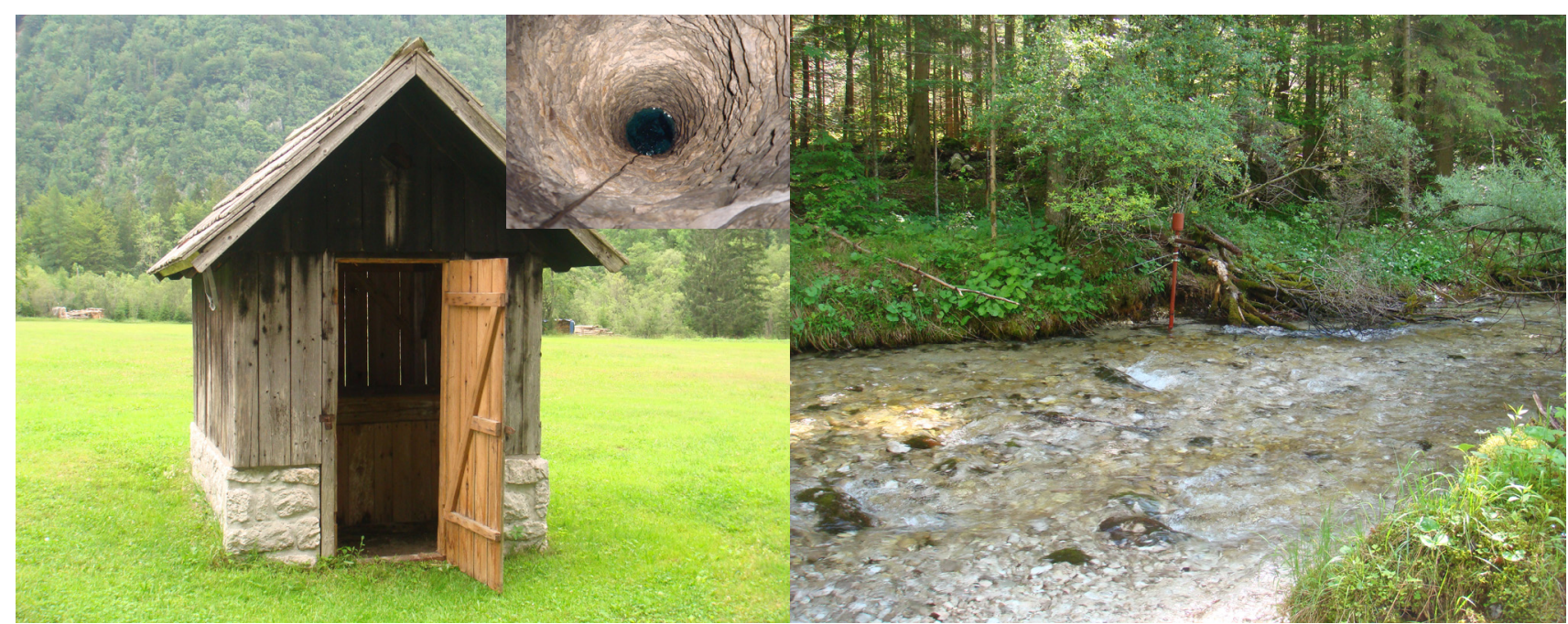

Fig. 5. The well location.

\section{Measurements of groundwater level and discharge}

The groundwater level was measured in a hand-dug well in the hinterland of the Radovna spring (Figs. 2, 5). The depth of the well is 28 meters. The well is dry almost every winter for approximately four months due to low waters and is dry until the snowmelt in the late spring.

The Gogalov Rovt water level station is downstream from the spring, where the discharge in the stream is in one uniform channel (Figs. 2, 6). On this location the discharge is always present, except at the beginning of our investigations, in March 2012, when the climate conditions were very dry, the channel dried up. The water level in the well and at the Gogalov Rovt location was measured every hour with level data logger (Eltratec). The discharge at the Gogalov Rovt was measured with dilution method (Flo-Tracer instrument) and with hydrometric current-meter (A.OTT KEMPTEN Type C2 »10.150«) (Boiten, 2008).

Table 3. GPR processing steps.

\begin{tabular}{|c|c|}
\hline Processing Step & Parameter \\
\hline DC Removal & $400-700 \mathrm{~ns}$ \\
\hline $\begin{array}{c}\text { Time-Zero } \\
\text { Adjustment }\end{array}$ & First negative peak \\
\hline $\begin{array}{c}\text { Background } \\
\text { Removal }\end{array}$ & Normal \\
\hline Gain & Manual gain \\
\hline Bandpass Filtering & $\begin{array}{c}\text { Low-cut 25 MHz, lower plateau } \\
50 \mathrm{MHz}, \text { upper plateau 75 MHz, } \\
\text { high-cut } 150 \mathrm{MHz}\end{array}$ \\
\hline $\begin{array}{c}\text { Topographic } \\
\text { Correction }\end{array}$ & GNSS coordinates every $50 \mathrm{~m}$ \\
\hline
\end{tabular}

Fig. 6. The Gogalov Rovt location for measurements of river water level.

\section{Results and discussion}

\section{GPR}

\section{Data Processing}

For the GPR data processing, the program Reflexw version 6.0.5 from Sandmeier Software was used.

The processing steps were the same for all three radargrams (Tab. 3 ).

Since the profiles did not contain distinctive diffraction hyperbolas necessary to determine the signal velocity, the latter was calculated based on the depth of the groundwater level measured in the well. At the time of GPR measurements, the depth of groundwater in the well was $21.8 \mathrm{~m}$, which gave the signal velocity of $0.105 \mathrm{~m} / \mathrm{ns}$, corresponding to the material dielectric constant $\varepsilon=8$. These parameters reflect the fluvio-glacial deposits of the investigated area that consist of gravel, sand and partially conglomerate and are influenced by the presence of water. The dielectric constant of dry sand is in the range of $\varepsilon=3-6$, which is increased in our study by the presence of water (Jol, 2009).

\section{$G P R$ results}

In Fig. 7 the longitudinal profile $\mathrm{R} 1$ is shown together with marked features used to determine the groundwater level. The black frames indicate areas where a well-expressed linear reflector can be seen. This reflector is interrupted between the $500 \mathrm{~m}$ and $600 \mathrm{~m}$ profile distance (red frame). According to the geology of the area, the reason for this could be the presence of a larger block of rock block above the groundwater. Such isolated rock blocks occur along the entire Radovna Valley and 
in the nearby Krma Valley. The presence of such blocks could be the reason for greater signal attenuation, which means that the signal could not reach the groundwater level and this part of the radargram consequently does not contain a linear reflector. Another element, which was also used in the determining of the groundwater lev$\mathrm{el}$, is the location where water was first seen on the surface. With the help of these features, the level of the water table was depicted, while the measured depth of groundwater in the well and calculated signal velocity made it possible to accurately place it in the subsurface.

In addition to the depth and extent of the water table we also wanted to see, if the potential dip of the groundwater table is visible. The reason for this is that we wanted to check whether it would be possible to determine the groundwater gradient based on the GPR results. The gradient was determined using the depth of the groundwater table in the well, which was projected on the nearest point on the profile R1 $(722.06 \mathrm{~m}$ a.s.l.), and the depth at the intersection of the profiles R1 and R3 (719.20 $\mathrm{m}$ a.s.l.). The difference in the groundwater table of $2.86 \mathrm{~m}$ at a distance of $550 \mathrm{~m}$ gives the gradient 0.0052 . Despite the limited vertical resolution, such a difference should be seen in the radargram; however, the reflector representing the groundwater level appears to be more or less horizontal. This may be due to the fact that the profile was recorded in a very rugged terrain, causing poor contact between the GPR antenna and the ground. Thus, the groundwater level could not be determined with such accuracy that a gradient or even a concave groundwater table could be seen.

A continuous reflector representing the water table can also be seen on the profile R3 shown in Figure 8, where again it does not have a linear shape. This is due to the skipping of the antenna during recording over branches, roots and fallen trees. However, it is still possible to determine the groundwater table, which runs along the entire profile R3 at the depth of approximately $7.5 \mathrm{~m}$, corresponding to the depth determined at the intersection with the profile R1. Since the reflector is not perfectly smooth, using normal vertical to horizontal scale ratio of radargrams, it is hard to say whether or not the groundwater level is inclined due to an uneven recharge of groundwater from both sides of the valley. In Figure 8, the depth of the radargram is considerably exaggerated compared to its length and the dip of the water table towards $\mathrm{N}$ is visible. This means that the water recharge is higher from the $\mathrm{S}$ side of the valley, i.e. from the Pokljuka plateau. Along the whole profile R3, which is $354.5 \mathrm{~m}$ long, the difference in the depth of the inclined water table is about $1 \mathrm{~m}$.

R1
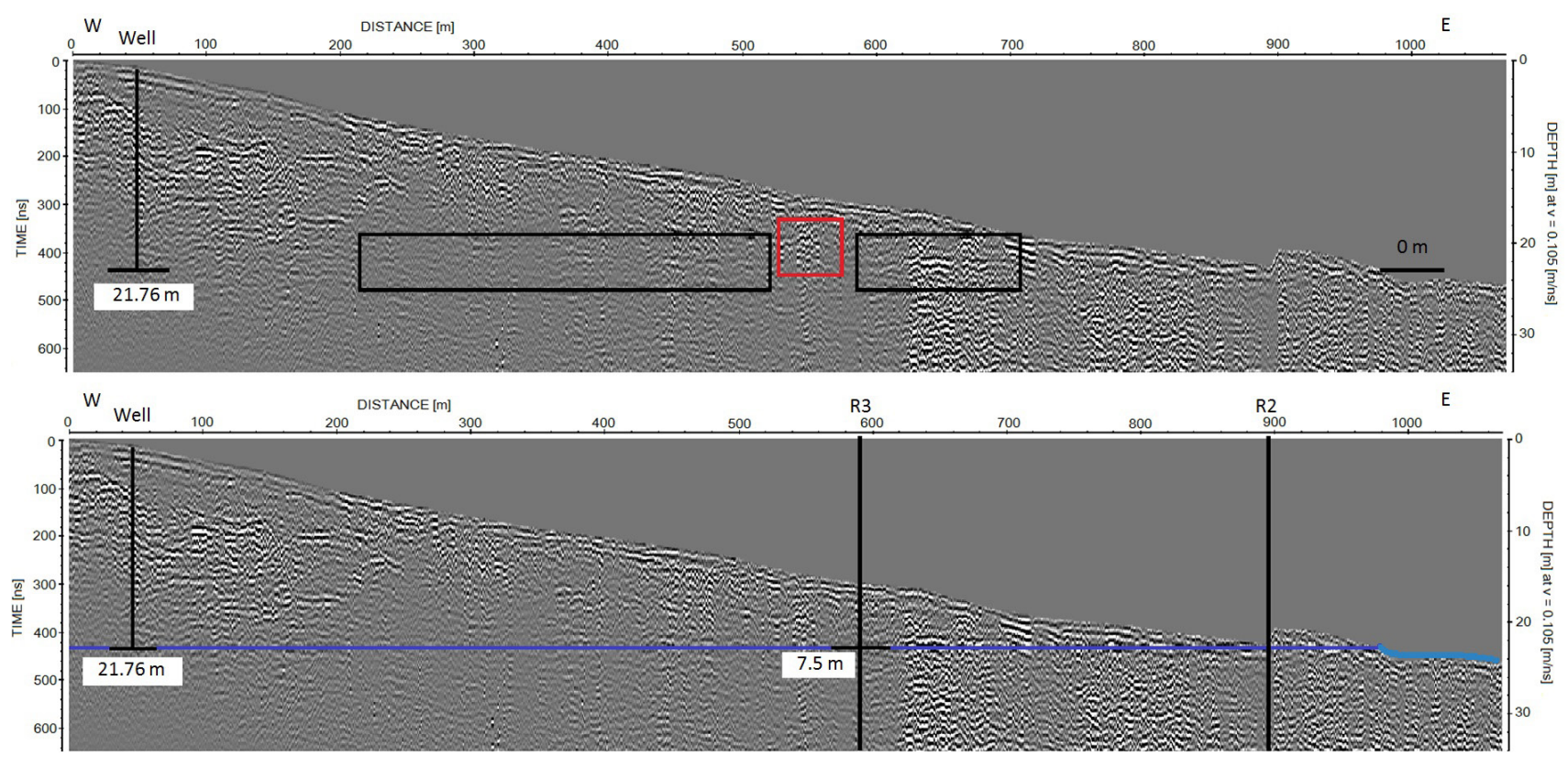

Fig. 7. Interpretation of longitudinal GPR profile R1. Top - features (black frames) used to determine the groundwater level with marked groundwater depth in the well $(21.76 \mathrm{~m})$, disrupted part of the reflector (red frame) and point where water was spotted on the surface - spring (dark blue line); bottom - construction of the groundwater level (light blue), water at the surface (dark blue), location of transverse profiles GPR R2 and R3 and groundwater depth at the intersection of profiles R1 and R3 $(7.5 \mathrm{~m})$. Vertical exaggeration is approx. $6 \times$. 
The transverse profile $\mathrm{R} 2$ was recorded in the area where the groundwater is just below the surface. Due to the limited vertical resolution of the antenna used, this profile does not contain any linear reflectors, which also applies to the same location on the profile R1. The groundwater depth here is too shallow (probably less than $1 \mathrm{~m}$ ) to be detected by a low-frequency GPR method, which is optimal for greater depths, therefore this profile is not shown.
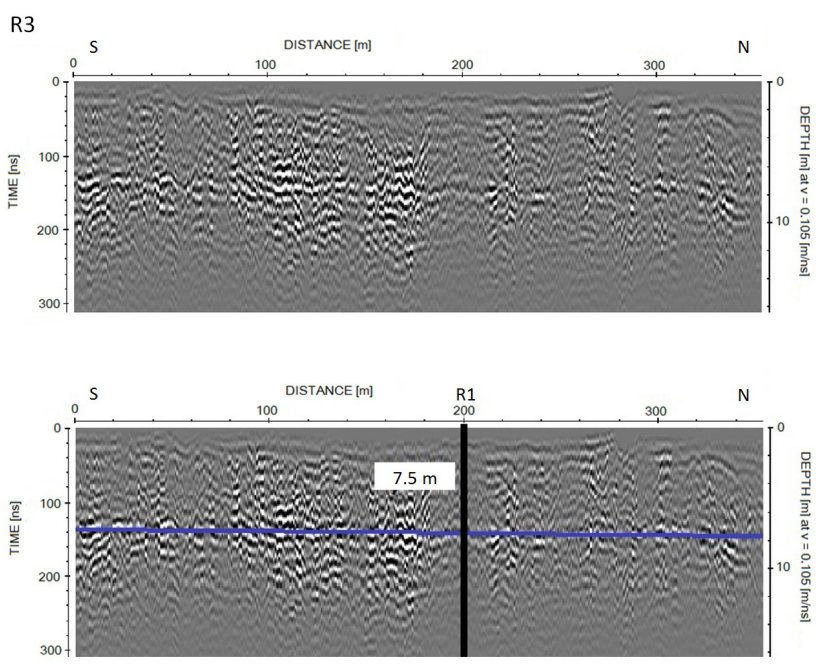

Fig. 8. Interpretation of transverse GPR profiles R3. Top well pronounced continuous reflector representing groundwater level; bottom - construction of the groundwater level (blue line) and marked location of intersection with longitudinal profile $\mathrm{R} 1$ and depth to groundwater $(7.5 \mathrm{~m})$. Vertical exaggeration is approx. $7 \times$

\section{Seismic reflection profile}

Obtained data quality for the HRS Radovna profile is highly variable (Fig. 9). The main contributing factors to the variability in data quality are natural noise due to the wind and vegetation and high signal attenuation. High signal attenuation is attributed to the large thickness $(20 \mathrm{~m})$ of the unsaturated zone of coarse-grained sediments, which acted as a signal dampener, particularly at high frequencies. On the day of the seismic reflection profiling the groundwater in the nearby well was 22.7 meters below the surface.

\section{Standard data processing}

Data was processed using Parallel Geoscience Seismic Processing Workshop software, first using a fairly standard seismic reflection data processing workflow, including data editing, geometry input, filtering, amplitude corrections, static corrections, velocity analysis and stacking (Tab. 4). In data editing only dead traces were removed. This was followed by early muting direct and refracted waves. Coherent noise was removed with velocity and f-k filters. Velocity analysis was performed using Constant Velocity Stack (CVS) as data quality was too low for useful velocity semblance analysis. Even CVS only produced useful results in the northern part of the profile between Common Mid-Point (CMP) 1120 and 1180. Normal moveout (NMO) stack was done with a constant stacking velocity of $2000 \mathrm{~m} / \mathrm{s}$ and $50 \%$ stretch mute.
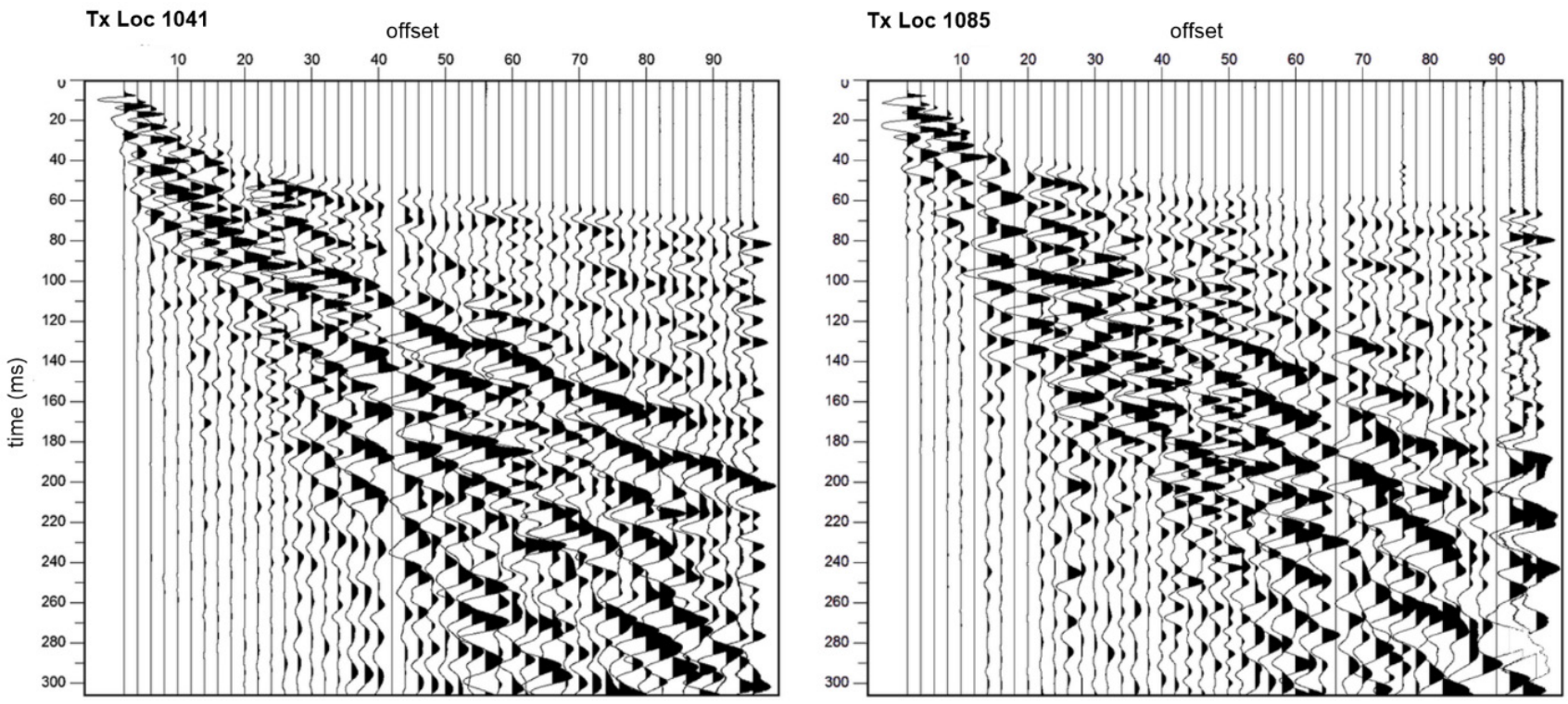

Fig. 9. Two seismic shot gathers displaying the variability in data quality. Left - shot gather at shot point Tx 1041 with almost indiscernible reflectors. Right - shot gather at shot point Tx 1085 with significantly better visibility of reflectors. 
Table 4. HRS Radovna profile standard data processing workflow.

\begin{tabular}{ll}
\hline Step & Details \\
\hline \hline Prestack & \\
Trace editing & low pass $40 \mathrm{~Hz}$, high pass $200 \mathrm{~Hz}$, low rolloff $18 \mathrm{~dB} /$ \\
Butterworth filtering & \\
$\begin{array}{l}\text { Early \& tail } \\
\text { mute }\end{array}$ & hand picked \\
$\begin{array}{l}\text { Spherical divergence correction } \\
\text { AGC }\end{array}$ & $80 \mathrm{~ms}$ window, $40 \mathrm{~ms}$ overlap \\
$\begin{array}{l}\text { F-k filtering (GR* and GW* attenuation) } \\
\text { Airwave attenuation }\end{array}$ & velocity filters \\
$\begin{array}{l}\text { Velocity analysis } \\
\text { Preliminary analysis }\end{array}$ & \\
Velocity semblance analysis & CVS (400-2000 m/s; $50 \mathrm{~m} / \mathrm{s}$ interval) \\
NMO correction \& stack & \\
NMO correction & \\
\hline \hline
\end{tabular}

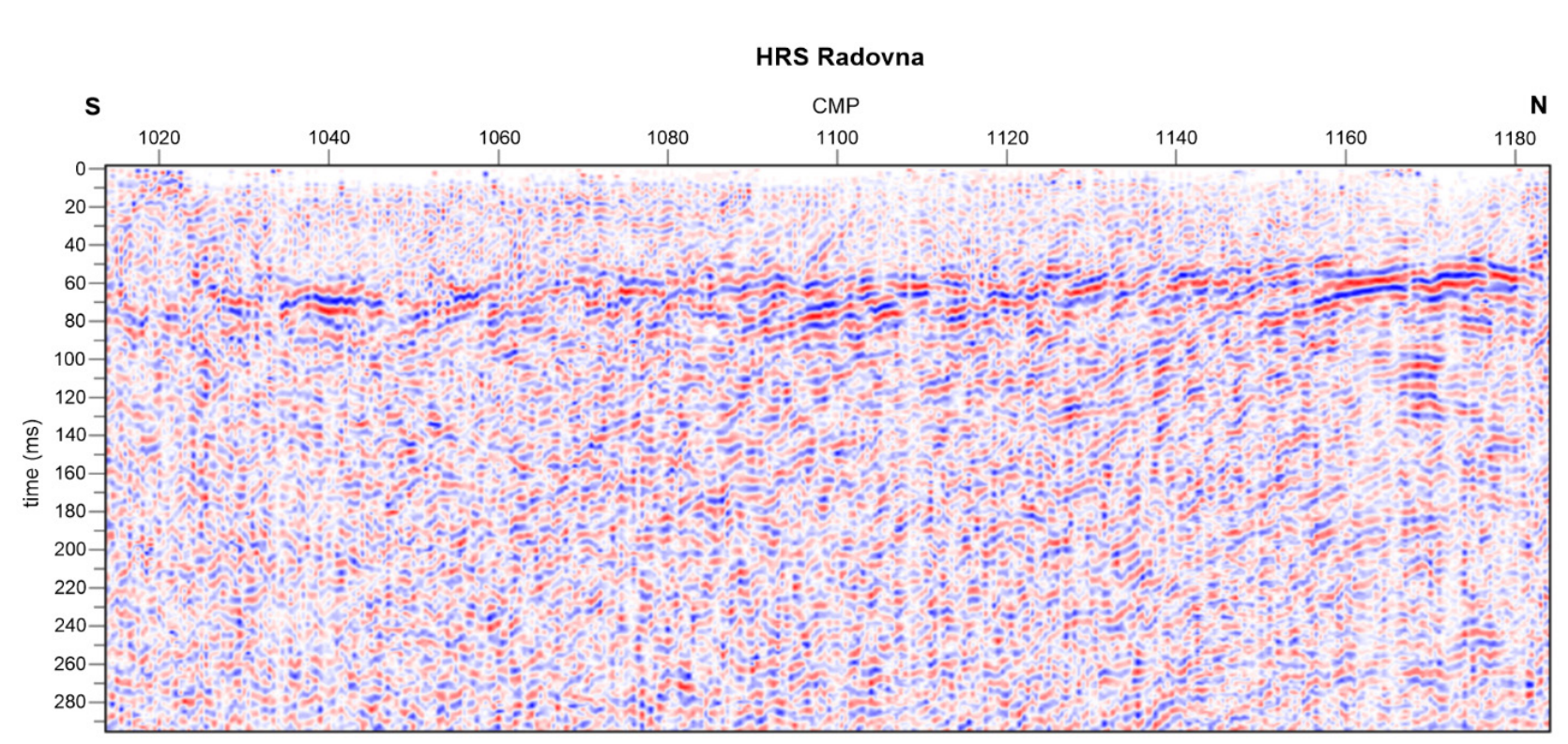

Fig. 10. Stacked section of the high-resolution seismic reflection profile across the Radovna Valley.

Most of the profile is dominated by very poor signal-to-noise ratio, with few reflectors distinguishable from background noise. A stronger southward dipping reflector is evident in the northern part of the profile between CMP 1120 and 1180 and TWT 60 to $130 \mathrm{~ms}$ (Fig. 10), which is interpreted as the pre-Quaternary basement Some fragmented reflectors are visible in the southern part of the profile at between 60 and $100 \mathrm{~ms}$ TWT, however, the generally poor data quality precludes any meaningful interpretation.

\section{Alternative data processing}

Due to the poor general data quality, an alternative approach was attempted in order to obtain some useful data on reflectors and their approximate depths. From the entire dataset, only high-quality shot gathers were selected. Selection criteria included: absence of random noise, low coherent noise and high clarity of seismic reflectors. A total of 9 shot gathers were selected (six of them shown on Fig. 11 and Tab. 5). On each shot gather all distinct reflectors were identified. 

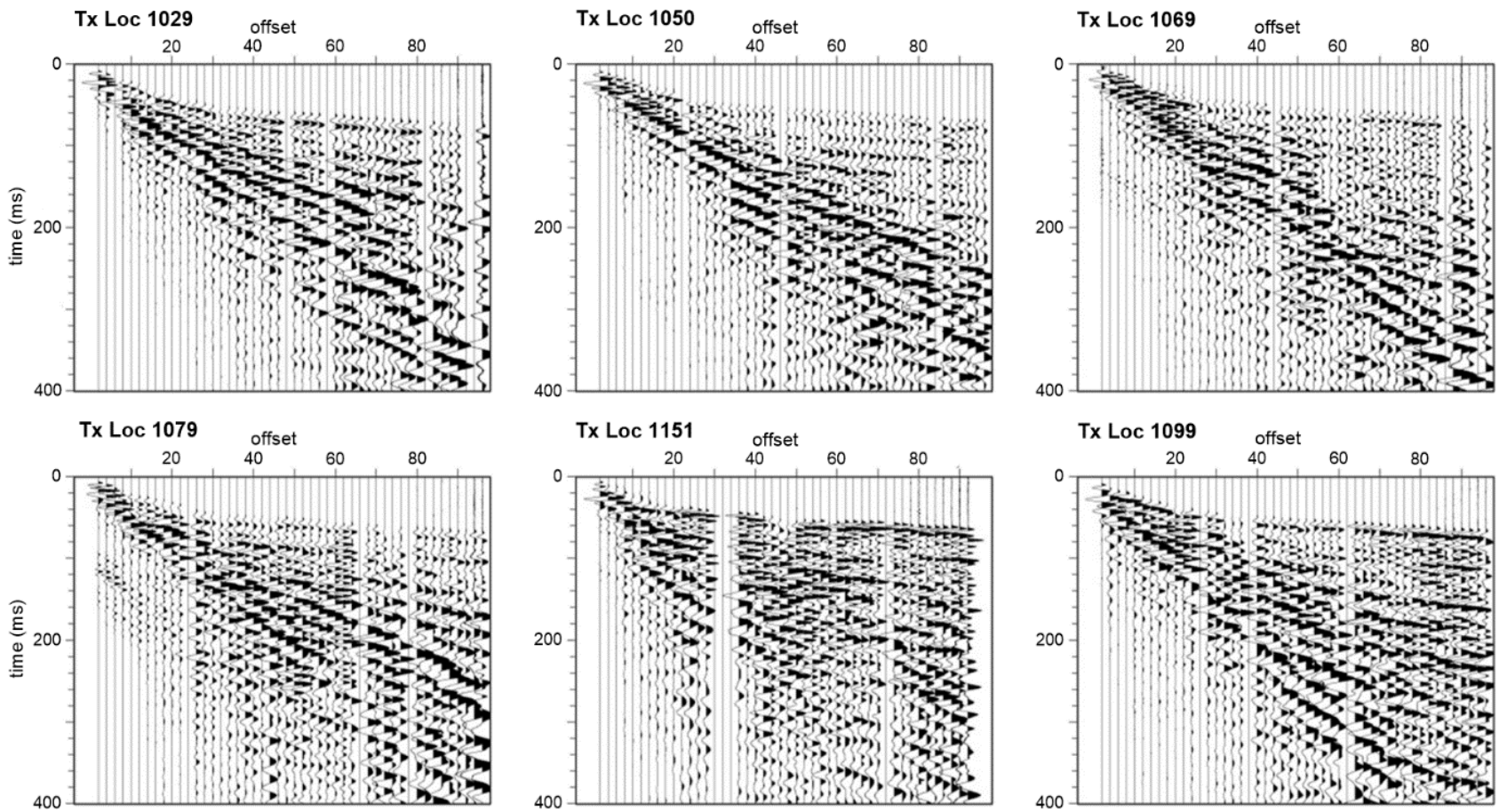

Fig. 11. Six of nine seismic shot gathers used in the alternative processing (shot points 1029, 1050, 1069, 1079, 1099 and 1151).

\begin{tabular}{|c|c|c|c|c|c|c|c|c|c|}
\hline CMP & $\begin{array}{l}\text { h1 } \\
\text { (m) }\end{array}$ & $\begin{array}{l}\text { h2 } \\
\text { (m) }\end{array}$ & $\begin{array}{l}\text { h3 } \\
\text { (m) }\end{array}$ & $\begin{array}{l}\text { h4 } \\
\text { (m) }\end{array}$ & $\begin{array}{l}\text { h5 } \\
\text { (m) }\end{array}$ & $\begin{array}{l}\text { h6 } \\
\text { (m) }\end{array}$ & $\begin{array}{l}\text { h7 } \\
\text { (m) }\end{array}$ & $\begin{array}{l}\text { h8 } \\
\text { (m) }\end{array}$ & $\begin{array}{c}\text { Bedrock } \\
\text { (m) }\end{array}$ \\
\hline 1029 & -37 & & -63 & -81 & & & -125 & & -125 \\
\hline 1050 & -37 & & -57 & -70 & -95 & -109 & -125 & -141 & -141 \\
\hline 1062 & & -40 & -59 & & -87 & -100 & -122 & & -122 \\
\hline 1079 & -34 & -43 & -55 & & -83 & & & & \\
\hline 1085 & -35 & -44 & -56 & & -86 & -117 & & & -117 \\
\hline 1099 & -28 & & -55 & -71 & -89 & -111 & & & -111 \\
\hline 1109 & -30 & & -49 & -66 & -89 & & & & \\
\hline 1115 & & -42 & & -65 & -95 & & & & -95 \\
\hline 1151 & -16 & & -53 & & & & & & -53 \\
\hline
\end{tabular}

Table 5. Selected seismic shot gathers with depths of interpreted reflectors arranged in nine horizons.

Approximate zero times of the reflectors were determined and then used as a basis for depth conversion.

\section{Hydrogeological interpretation}

For the purpose of building the model of the Radovna aquifer, data from all nine selected shot gathers was used. At each useful shot gathers individual reflectors were identified and their depth in TWT was estimated. All reflectors were depth converted (Tab. 5) using an average velocity $v_{p}$ of $2000 \mathrm{~m} / \mathrm{s}$, which is the average seismic wave velocity for glacial sediments (Kearey et al., 2002). It was assumed due to previous investigations that the reflectors within the valley fill sediments are generally horizontal or only slightly dipping, therefore reflections at similar depths were interpreted as the same reflector. From each selected shot point the deepest reflector was assumed as the depth to the pre-Quaternary basement and on the basis of these data, the shape of the basement was determined. We expect the depths to be accurate to within approximately $30 \%$, accounting for uncertainty in reflector zero times and potential variability in $\mathrm{v}_{\mathrm{p}}$ the valley fill. We expect the depths to be accurate to within approximately $30 \%$, accounting for uncertainty in reflector zero times and potential variability in $\mathrm{v}_{\mathrm{p}}$ the valley fill.

For the input structural model, the shape of the seismic horizons was linearly interpolated between the data points. Due to the lack of borehole data, it is impossible to characterize the lithological boundaries or sediment transitions that produced the reflectors. It is possible that reflectors are produced by either a major change in grain 
sizes in glacial till (different moraine types) or between different types of sediment, such as glacial till, alluvial and glaciofluvial sediments.

From the interpolated data, the schematic cross-section of the valley was plotted (Fig. 12). Since the profile could not be obtained throughout the whole width of the valley, the extrapolated part is represented with dashed line. The line was truncated at the edge of a large pasture, enclosed by an electric fence and occupied by cattle which precluded measurements. Additionally, the very soft grassy surface was inappropriate for data acquisition using impact sources due to high signal attenuation - an effect which has been described elsewhere under similar conditions (Atanackov \& Gosar, 2013).

Based on previous research, it is assumed that results represent some sort of stratification of sediments and most likely to reflect the difference between well and poorly granulated sandy gravel layers and layers with glacial dropstones. With the analysis at least seven different layers were determined (Fig. 10). The deepest point of the pre-Quaternary basement is 141 meters deep and was determined with only one shot gather. Though the lack of data, this depth is realistic according to previous investigations in this area, where the depth of the sediments was determined to be at least 100 meters (Torkar \& Brenčič, 2015). Similar seismic reflection investigations were done in the area of Sava springs area in a similar parallel valley, where the pre-Quaternary basement was determined to be at the depth of $200 \mathrm{~m}$ and is linked to the Sava fault zone (Atanackov et al., 2015). The southern slope of the buried valley is steeper than the northern slope. This corresponds to the shape of valley above the surface. The morphology of the pre-Quaternary basement is realistic in the whole width of the valley, except between 200 and 300 meters distance, where it is very steep.

\section{Fluctuation of groundwater level and discharge}

Groundwater level in the well (Figs. 2, 5) was measured hourly in the period from 4.10.2011 to 12.4.2016 and contains 37.934 data. Since the well dries up in the winter, the missing data was supplemented with the recession curve, where the data were processed with exponential regression (Posavec et al., 2006; 2010).

During the entire investigation (10/201104/2016) we managed to record, both the dry period and floods. From mid-2011 and mid-2012 there was a drought period (ARSO, 2012). In the same year, there was a lot of precipitation, which caused flooding. The fluctuation of the groundwater level in the well is very dynamic. With the instrument we recorded a range of fluctuations up to $19.11 \mathrm{~m}$. With the construction of the curve (dashed line) we recorded a range of fluctuations of up to $28.6 \mathrm{~m}$ (Fig. 13), which is much more than previously determined. The groundwater level was the lowest recorded, with the help of a reconstruction, on 11 March 2012 at an altitude of $708.3 \mathrm{~m}$ and the highest on 10.11.2012 at an altitude of $736.9 \mathrm{~m}$. The well dried each year, with the exception of 2014, when precipitation in that area was $2394.2 \mathrm{~mm}$, which represents $126 \%$ of the precipitation relative to the reference period 1961-1990.

The groundwater level in the upper part of the Radovna River Valley fluctuates greatly and changes rapidly, indicating well-permeable aquifer, and at the same time such an aquifer is extremely sensitive and vulnerable to extreme climatic events such as drought or lack of snow and

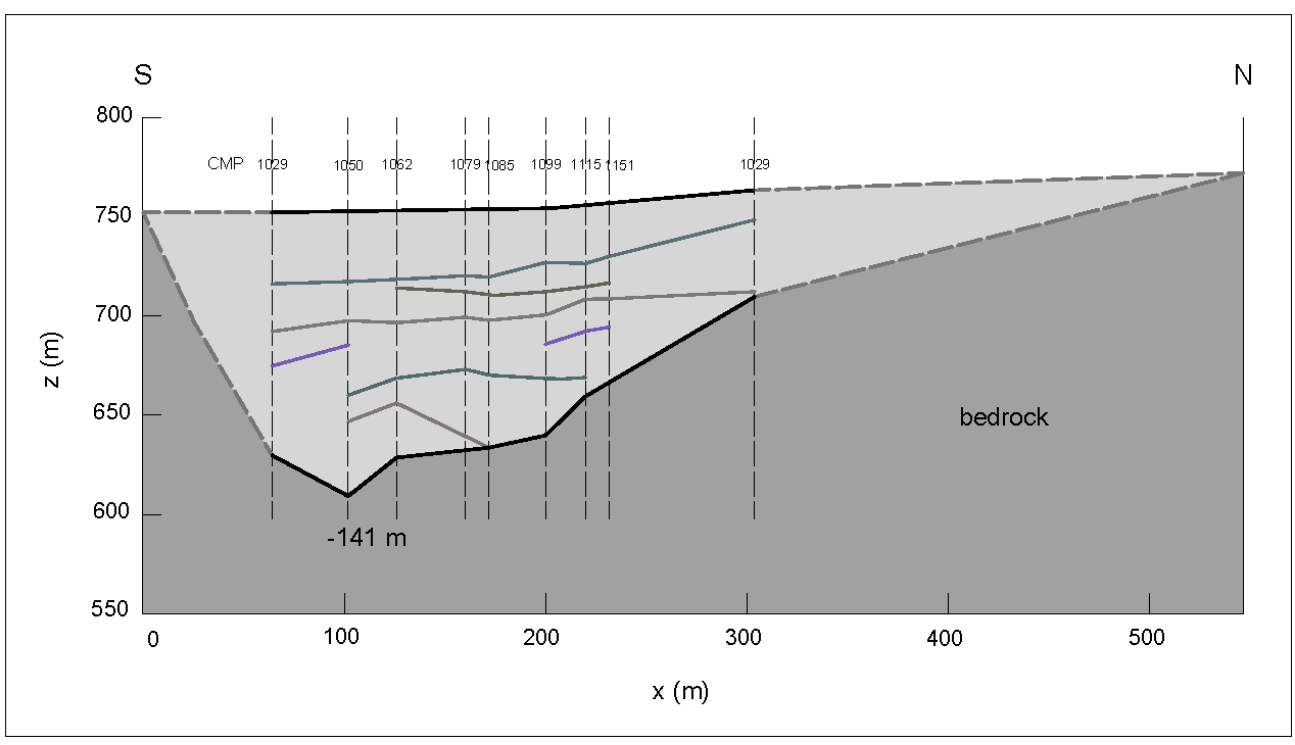

Fig. 12. Schematic N-S cross-section model of the Radovna River Valley derived from HRS profile. 

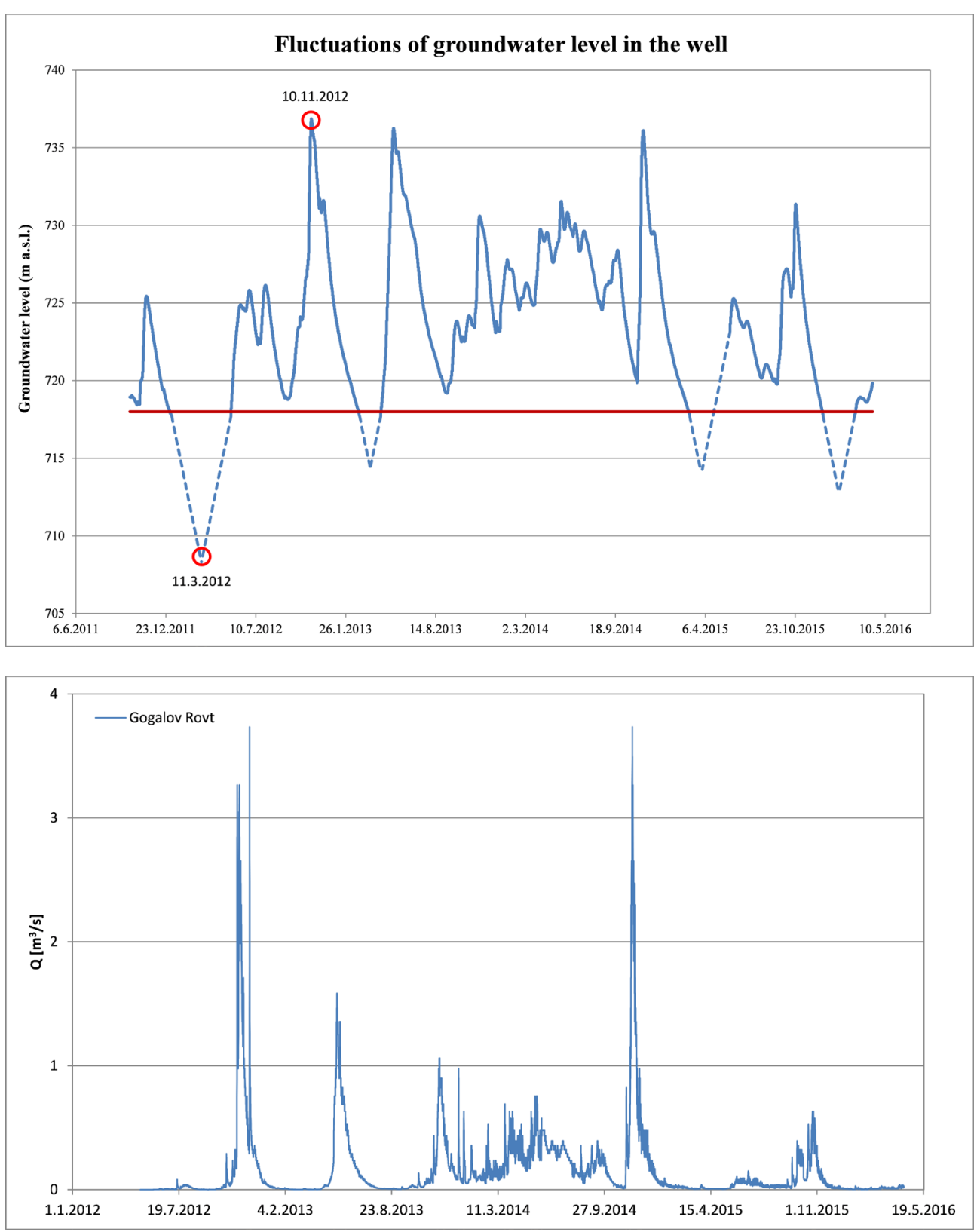

Fig. 13. The fluctuation of the groundwater level in the well in time; dashed line marks the calculated levels by recession curve, the red line indicates the depth of the well.
Fig. 14. Discharge of Radovna river as a function of time at location Gogalov Rovt. floods, or too much water in a short time, which can cause a lot of damage. The fluctuations of the groundwater level are simultaneously reflected at the location of the Radovna Spring, as it moves along the valley up and down according to the amount of water in the aquifer.

At the Gogalov Rovt location (Figs. 2, 6) discharge was measured from 1.3.2012 to 12.4.2016. At the beginning of the measurements the riverbed was dry till the beginning of May, due to extremely low precipitations in 2011 and 2012. The discharge ranged between 0 and $3.74 \mathrm{~m}^{3} / \mathrm{s}$, with an average of $0.16 \mathrm{~m}^{3} / \mathrm{s}$ (Fig. 14).

The Gogalov Rovt hydrograph shows a mixed, Alpine snow-rain drainage regime, with minimal discharges in the winter and summer periods and with maximum discharges in spring, during snow melting period, and in autumn during heavy precipitations. The fluctuations of discharges in the river are a reflection of the fluctuation of the groundwater level in the aquifer and the direct impact of precipitation. In case of heavy precipitation the water in the riverbed increases greatly, but also drains very quickly. The snow melting periods are very different during the observation period on the hydrograph, which is influenced by several factors, such as the thickness of the snow cover, the temperature at the melting time, the amount of rainfall, etc.

\section{Conclusions}

The low-frequency GPR method has shown to be useful for determining the depth of the groundwater table in the hinterland of the Radovna spring. Given the rather unfavourable conditions for GPR measurements that caused 
poor antennas ground contact, the results are satisfactory. Although it was impossible to determine the shape of the groundwater table in detail, an insight into the aquifer and calculation of groundwater gradient was obtained with the longitudinal profile R1. A greater recharge from the southern Pokljuka plateau was detected in the transverse profile R3.

The high-resolution seismic reflection profile provided, despite generally poor data quality and necessity to apply alternative interpretation method, highly valuable information on the geometry of the aquifer and the depth of the sediments in the valley. The seismic reflection data gave an insight about the morphology of the pre-Quaternary basement with the deepest point at 141 meters below surface.

Measurements of the groundwater level showed that the fluctuations were very dynamic reaching up to 19.11 meters, and even, 28.6 meters when the curve was extrapolated. Surface water discharges ranged between 0 and $3.74 \mathrm{~m}^{3} / \mathrm{s}$, with an average of $0.16 \mathrm{~m}^{3} / \mathrm{s}$, showing a mixed, Alpine snow-rain drainage regime. The fluctuation of groundwater level is directly reflected in the discharges in the river, as the location of the Radovna Spring moves up and down depending on the amount of water in the aquifer.

Both the geophysical and hydrogeological methods provided important information on the morphology of the valley and the alluvial aquifer, adding to the knowledge of the Radovna springs system and providing very important information for future hydrogeological investigations.

\section{Acknowledgment}

The GPR survey was conducted with the support of the Slovenian Research Agency PhD grants 100010-310073 and 1000-10-310074. HRS data acquisition was supported by Slovenian Research Agency programme grant P1-0011.

\section{References}

Afshar, A., Abedi, M., Norouzi, G.-H. \& Riahi, M.-A. 2015: Geophysical investigation of underground water content zones using electrical resistivity tomography and ground penetrating radar: A case study in Hesarak-Karaj, Iran. Engineering Geology, 196: 183-193. http://dx.doi.org/10.1016/j.enggeo.2015.07.022

Annan, A. P. 2002: GPR-History, Trends, and Future Developments. Subsurface Sensing Technologies and Applications, 3: 253-270. https://doi.org/10.1023/a:1020657129590
Atanackov, J., Car, M., Jamšek Rupnik, P., Jež, J., Celarc, B., Novak, M., Milanič, B., Šram, D. \& Bavec, Š. 2015: Poročilo o geofizikalnih raziskavah in geološka sinteza raziskav območja Zelencev in Ledin. Geološki zavod Slovenije.

Atanackov, J. \& Gosar, A. 2013: Field comparison of seismic sources for high resolution shallow seismic reflection profiling on the Ljubljana moor. Acta Geodynamica et Geomaterialia, 10/1: 19-40. https://doi.org/10.13168/ AGG.2013.0002

Blindow, N., Eisenburger, D., Illich, B., Petzold, H. \& Richter, T. 2007: Ground Penetrating Radar. Environmental Geology: Handbook of Field Methods and Case Studies. Berlin, Heidelberg: Springer Berlin Heidelberg.

Boiten, W. 2008: Hydrometry 3rd Edition: A comprehensive introduction to the measurement of flow in open channels, Leiden, CRC Press Balkema.

Bowling, J. C., Harry, D. L., Rodriguez, A. B. \& Zheng, C. 2007: Integrated geophysical and geological investigation of a heterogeneous fluvial aquifer in Columbus Mississippi. Journal of Applied Geophysics, 62: 58-73. https://doi.org/10.1016/j.jappgeo.2006.08.003

Buser, S. 1980: Osnovna geološka karta SFRJ. 1: 100.000, Tolmač lista Celovec (Klagenfurt) L 33-53, Beograd, Zvezni geološki zavod.

Doolittle, J. A., Jenkinson, B., Hopkins, D., Ulmer, M. \& Tuttle, W. 2006: Hydropedological investigations with ground-penetrating radar (GPR): Estimating water-table depths and local ground-water flow pattern in areas of coarse-textured soils. Geoderma, 131: $317-329$. https://doi.org/10.1016/j. geoderma.2005.03.027

Ferjan Stanič, T., Brenčič, M. \& Zupančič, N. 2013: Heavy metal concentrations in soil in the vicinity of former ironworks in Spodnja Radovna, Slovenia. Geologija, 56/2: 229-241. https://doi.org/10.5474/geologija.2013.015

Iskra, M. 1982: Elaborat o klasifikaciji, kategorizaciji in izračunu zalog jezerske krede na območju odkopa v Srednji Radovni. [Poročilo v arhivu Geološkega zavoda Slovenije] Geološki zavod Ljubljana.

Jol, H. M. 2009: Ground Penetrating Radar Theory and Applications: theory and applications Amsterdam, Elsevier.

Jurkovšek, B. 1987: Osnovna geološka karta SFRJ 1:100.000, Tolmač listov Beljak in Ponteba: L 33-51 L 33-52, Beograd, Zvezni geološki zavod. 
Kaiser, A. E., Green, A. G., Campbell, F. M., Horstmeyer, H., Manukyan, E., Langridge, R. M., Mcclymont, A. F., Mancktelow, N., Finnemore, M. \& Nobes, D. C. 2009: Ultrahighresolution seismic reflection imaging of the Alpine Fault, New Zealand. Journal of Geophysical Research: Solid Earth, 114, B11. https://doi.org/10.1029/2009jb006338

Kanduč, T., Mori, N., Kocman, D., Stibilj, V. \& Grassa, F. 2012: Hydrogeochemistry of Alpine springs from North Slovenia: Insights from stable isotopes. Chemical Geology, 300/301: 40-54. https://doi.org/10.1016/j. chemgeo.2012.01.012

Kearey, P., Brooks, M. \& Hill, I. 2002: An introduction to geophysical exploration, Malden, MA: Blackwell Science, cop. 2002.

Mahmoudzadeh, M. R., Francés, A. P., Lubczynski, M. \& Lambot, S. 2012: Using ground penetrating radar to investigate the water table depth in weathered granites - Sardon case study, Spain. Journal of Applied Geophysics, 79: 17-26. https://doi. org/10.1016/j.jappgeo.2011.12.009

Malå 2009: ProEx-Professional explorer control unit. Operating manual v 2.0.

Mcclymont, A. F., Hayashi, M., Bentley, L. R. \& Liard, J. 2012: Locating and characterising groundwater storage areas within an alpine watershed using time-lapse gravity, GPR and seismic refraction methods. Hydrological Processes, 26: 1792-1804. https://doi. org/10.1002/hyp.9316

Milsom, J. 2003. Field Geophysics, West Sussex, John Wiley \& Sons Ltd.

Nadbath, M. 2012: Meteorološka postaja Zgornja Radovna. Naše okolje, Bilten Agencije RS za okolje, XIX, 1-5.

Neal, A. 2004: Ground-penetrating radar and its use in sedimentology: principles, problems and progress. Earth-Science Reviews, 66/3-4: 261-330. https://doi.org/10.1016/j. earscirev.2004.01.004

Paz, C., Alcalá, F. J., Carvalho, J. M., Ribeiro, L. 2017: Current uses of ground penetrating radar in groundwater-dependent ecosystems research. Sci Total Environ., 595: 868-885. https://doi.org/10.1016/j.scitotenv.2017.03.210

Posavec, K., Bačani, A. \& Nakić, Z. 2006: A Visual Basic Spreadsheet Macro for Recession Curve Analysis. Ground Water, 44: 764-767. https:// doi.10.1111/j.1745-6584.2006.00226.x

Posavec, K., Parlov, J. \& Nakić, Z. 2010. Fully Automated Objective-Based Method for Master Recession Curve Separation. Ground Water, 48: 598-603. https://doi. org/10.1111/j.1745-6584.2009.00669.x

Rejiba, F., Bobée, C., Maugis, P. \& Camerlynck, C. 2012: GPR imaging of a sand dune aquifer: A case study in the niayes ecoregion of Tanma, Senegal. Journal of Applied Geophysics, 81: $\quad$ 16-20. https://doi.org/10.1016/j. jappgeo.2011.09.015

Torkar, A. \& Brenčič, M. 2015: Spatio-temporal distribution of discharges in the Radovna River valley at low water conditions. Geologija, 58/1: 47-56. https://doi.org/10.5474/ geologija.2015.003

Torkar, A., Brenčič, M. \& Vreča, P. 2016: Chemical and isotopic characteristics of groundwater-dominated Radovna River (NW Slovenia). Environmental Earth Sciences, 75: 1-18. https://doi.org/10.1007/s12665-016-6104-5

Yilmaz, Ö. \& Doherty, S. M. 2001: Seismic Data Analysis: Processing, Inversion, and Interpretation of Seismic Data, Society of Exploration Geophysicists.

Zajc, M., Celarc, B. \& Gosar, A. 2015: Structuralgeological and karst feature investigations of the limestone-flysch thrust-fault contact using low-frequency ground penetrating radar (Adria-Dinarides thrust zone, SW Slovenia). Environmental Earth Sciences, 73: 8237-8249. https://doi.org/10.1007/ S12665-014-3987-X

Zajc, M., Pogačnik, Ž. \& Gosar, A. 2014: Ground penetrating radar and structural geological mapping investigation of karst and tectonic features in flyschoid rocks as geological hazard for exploitation. International Journal of Rock Mechanics and Mining Sciences, 67: 78-87. https://doi.org/10.1016/j. ijrmms.2014.01.011 